Jurnal Ilmiah Matematika dan Pendidikan Matematika (JMP)

Vol. 12 No. 2, Desember 2020, Hal. 15-28

ISSN (Cetak) : 2085-1456; ISSN (Online) : 2550-0422

\title{
ANALISIS ASSESMENT SALES RATIO PADA NILAI JUAL OBJEK PAJAK DENGAN ZONA NILAI TANAH TERHADAP STANDAR YANG DITETAPKAN IAAO
}

\author{
Nurul Azizah Baisaku \\ Jurusan Matematika, FMIPA Universitas Jenderal Soedirman \\ nurul.baisaku@mhs.unsoed.ac.id \\ Bambang Hendriya Guswanto \\ Jurusan Matematika, FMIPA Universitas Jenderal Soedirman \\ bambang.guswanto@unsoed.ac.id \\ Dian Linawati \\ Badan Pertanahan Nasional (BPN) Kabupaten Cirebon
}

\begin{abstract}
Land values in NJOP used as a basis for taxing land are often different from land values in the Land Value Zone (ZNT). The difference in land values contained in the NJOP and ZNT causes uncertainty about local tax revenue and creates injustice for the government and the community. Based on this, an analysis of Assesment Sales Ratio (ASR) is used to determine the determination of land values in NJOP with ZNT against the standard size determined by the International Association of Assessing Officers (IAAO). The results of the ASR analysis show that the determination of NJOP in Pamijahan Village, Plumbon District, Cirebon Regency is outside the standard range set by the IAAO, which is 0.90 to 1.10 (90\% -110\%). This can be seen from the results of the measurement of central tendency, which is a mean of 10.53\%, a median of 0.1037, and a weighted mean of $6.136 \%$. The comparisons between components of the measurement results of the central tendency indicate the occurrence of regressivity or downtrend. The Assessment Ratio in Pamijahan Village, Plumbon District, Cirebon Regency also did not show good uniformity, as indicated by a COD value of $0.66 \%$ and a COV value of $70.02 \%$ which were outside the standard set by IAAO i.e. the minimum and maximum values for COD and COV are 5\% and 20\%, respectively.
\end{abstract}

Keywords: Tax Object Sales Value (NJOP), Assessment Sales Ratio (ASR), International Association of Assessing Officers (IAAO).

ABSTRAK. Nilai tanah pada NJOP yang digunakan sebagai dasar dalam pengenaan
pajak suatu tanah sering kali berbeda dengan nilai tanah yang ada pada Zona Nilai Tanah
(ZNT). Perbedaan nilai tanah yang terdapat pada NJOP dan ZNT menyebabkan ketidak
pastian penerimaan pajak daerah dan menimbulkan ketidak adilan bagi pemerintah dan
masyarakat. Berdasarkan hal tersebut, digunakan analisis Assesment Sales Ratio guna
mengetahui penetapan nilai tanah pada NJOP dengan ZNT terhadap ukuran standar yang
ditetapkan oleh International Association of Assessing Officers (IAAO). Hasil analisis
ASR menunjukkan bahwa penetapan NJOP di Desa Pamijahan, Kecamatan Plumbon, 
Kabupaten Cirebon berada di luar rentang standar yang ditetapkan IAAO yaitu sebesar 0,90 sampai dengan 1,10 (90\%-110\%). Hal ini terlihat dari hasil pengukuran tendensi sentral, yaitu mean sebesar $10,53 \%$, median sebesar 0,1037 , dan weighted mean sebesar $6,136 \%$. Serta perbandingan antar komponen hasil pengukuran tendensi sentral menunjukkan terjadinya regresivitas atau kecenderungan turun. Assessment Ratio di Desa Pamijahan, Kecamatan Plumbon, Kabupaten Cirebon juga tidak menunjukkan keseragaman yang baik, yang ditunjukkan dengan nilai COD sebesar $0,66 \%$ dan nilai COV sebesar 70,02\% yang berada di luar standar yang ditetapkan oleh IAAO yaitu nilai COD dan COV minimal 5\% dan maksimal $20 \%$.

Kata Kunci: Nilai Jual Objek Pajak (NJOP), Assessment Sales Ratio (ASR), International Association of Assessing Officers (IAAO).

\section{PENDAHULUAN}

\subsection{Latar Belakang}

Secara fisik, tanah dapat didefinisikan sebagai permukaan bumi bersamasama dengan tubuh bumi yang berada dibawahnya. Oleh karena itu, bagi mereka yang memperoleh manfaat dari bumi dan kekayaan alam yang terkandung di dalamnya wajib untuk menyerahkan sebagian kenikmatan yang diperolehnya kepada Negara melalui Pajak (Bagian Umum UU No.12 Tahun 1985 yang diubah dengan UU No.12 Tahun 1994 Tentang Pajak Bumi dan Bangunan). Pajak yang dikenakan bagi mereka yang memperoleh manfaat dari bumi dan kekayaan alam yang terkandung di dalamnya adalah Pajak Bumi dan Bangunan (PBB).

Dasar yang digunakan untuk mengenakan Pajak Bumi dan Bangunan adalah Nilai Jual Obyek Pajak (NJOP). Sesuai Pasal 6 ayat 2 UU No. 12/1985 mengenai besarnya NJOP ditetapkan setiap tiga tahun oleh Menteri Keuangan, kecuali untuk daerah tertentu ditetapkan setiap tahun sesuai perkembangan daerahnya, terutama apabila daerah tersebut mengalami kemajuan nilai ekonomis tanah. Nilai jual objek pajak ditentukan berdasarkan harga rata-rata dari transaksi jual beli, maka dalam pelaksanaan pengenaan PBB di lapangan dapat saja NJOP lebih tinggi atau lebih rendah dari transaksi jual beli yang dilakukan masyarakat.

Selain dengan NJOP, informasi nilai tanah dapat diketahui dengan zona nilai tanah (ZNT) yang dikeluarkan oleh Kementerian Agraria dan Tata Ruang/Badan Pertanahan Nasional. Zona nilai tanah (ZNT) merupakan kumpulan area yang terdiri dari beberapa bidang tanah dengan nilai tanah yang relatif sama dan batasannya bersifat imajiner atau nyata sesuai penggunaan tanahnya. Pada 
dasarnya ZNT dan NJOP sama-sama menginformasikan nilai pasar tanah. Namun, harga tanah pada NJOP maupun ZNT seringkali menunjukkan nilai yang berbeda satu sama lain. Hal ini dikarenakan adanya penyimpangan-penyimpangan yang dilakukan oleh masyarakat dengan cara melaporkan harga transaksi yang lebih rendah dari harga sebenarnya kepada pihak terkait dengan tujuan membayar pajak dengan nilai yang lebih rendah. Dengan demikian, data pasar yang menjadi acuan sebagai dasar penetapan NJOP tanah menjadi tidak akurat. Ketidakakuratan NJOP mengakibatkan ketidaksesuaian antara penetapan Pajak Bumi dan Bangunan (PBB) dan Bea Perolehan Hak Atas Tanah dan Bangunan (BPHTB) dengan kenyataan yang ada di lapangan. Dalam rangka menjunjung asas keadilan, pemerataan dan kepastian hukum bagi berbagai pihak maka perlu dilakukan analisis penilaian tanah. Metode Assessment Sales Ratio (ASR) dapat digunakan untuk menganalisis tingkat keakuratan NJOP yang ditetapkan.

Metode Assessment Sales Ratio dapat digunakan dalam hal penetapan, keseragaman, keadilan, mengidentifikasi berbagai permasalahan seputar analisis pasar, penyelesaian keberatan prosedur penilaian dan masalah lainnya. Metode analisis rasio yang sering digunakan dalam bidang penilaian properti untuk kepentingan perpajakan adalah Assessment Sales Ratio yang merupakan perbandingan antara NJOP sebagai nilai properti yang ditetapkan terhadap nilai pasar (market value). Dengan metode Assessment Sales Ratio ini dapat diketahui bagaimana penerapan NJOP tanah dengan nilai pasar yang berlaku di masyarakat berdasarkan standar International Association of Assessing Officers (IAAO).

Desa Pamijahan, Kecamatan Plumbon merupakan salah satu desa yang ada di Kabupaten Cirebon. Nilai Jual Objek Pajak di Desa Pamijahan, Kecamatan Plumbon, Kabupaten Cirebon banyak ditemukan berbeda dari ZNT yang ada atau harga pasar tanah setempat. Sifat NJOP yang cenderung statis dan harga pasar yang dinamis (terus berubah mengikuti zaman) merupakan masalah dasar yang menyebabkan perbedaan nilai antara NJOP dan ZNT Desa Pamijahan, Kecamatan Plumbon, Kabupaten Cirebon. Perbedaan antara NJOP dan ZNT menjadikan tingkat akurasi penetapan NJOP terhadap nilai pasar di Desa Pamijahan, Kecamatan Plumbon, Kabupaten Cirebon perlu diteliti. 


\subsection{Rumusan Masalah}

Berdasarkan uraian di atas, permasalahan yang dihadapi adalah apakah hasil dari analisis Assessment Sales Ratio (ASR) yang diterapkan di Desa Pamijahan, Kecamatan Plumbon, Kabupaten Cirebon sudah sesuai dengan standar yang ditetapkan oleh International Association of Assessing Officers (IAAO) dan bagaimana kecenderungan dan keseragaman NJOP di Desa Pamijahan, Kecamatan Plumbon, Kabupaten Cirebon.

\subsection{Tujuan}

Tujuan yang dapat dicapai dari kerja praktik ini adalah menentukan kesesuaian hasil dari analisis Assessment Sales Ratio (ASR) yang diterapkan di Desa Pamijahan, Kecamatan Plumbon, Kabupaten Cirebon dengan standar yang ditetapkan oleh International Association of Assessing Officers (IAAO) dan mengetahui kecenderungan dan keseragaman NJOP di Desa Pamijahan, Kecamatan Plumbon, Kabupaten Cirebon.

\subsection{Manfaat}

Manfaat yang diharapkan dari penelitian ini, antara lain:

1. Sebagai pertimbangan dalam penentuan Nilai Jual Obek Pajak agar didapatkan keadilan dalam nilai tanah

2. Sebagai bahan pustaka untuk penelitian selanjutnya dalam melakukan penyelesaian masalah dalam menentukan Nilai Jual Objek Pajak disuatu daerah

\section{METODE PENELITIAN}

\subsection{Data}

Jenis data yang digunakan adalah data sekunder yaitu data NJOP yang diperoleh dari Dinas Pendapatan Daerah Kabupaten Cirebon, peta blok, peta pendaftaran, dan peta ZNT Desa Pamijahan, Kecamatan Plumbon, Kabupaten Cirebon yang diperoleh dari ATR/BPN Kabupaten Cirebon. 


\subsection{Prosedur Penelitian}

Analisis Data merupakan tahapan pertama yang dilakukan untuk menganalisis data yang diperoleh untuk penentuan nilai nilai NJOP dan ZNT pada suatu daerah yang dipilih. Yang kemudian akan dilakukan overlay peta antara peta bidang, peta pendaftaran, peta blok dan peta ZNT.

Analisis Assesment Sales Ratio digunakan dalam menyelesaikan penelitian ini karena analisis dengan menggunakan ASR biasanya digunakan dalam menyelesaikan permasalahan yang berkaitan dengan nilai tanah atau pajak pada suatu daerah. Pada ASR ini, mula mula perlu dilakukan penentuan nilai AR, pengukuran tendensi sentral, perbandingan antara komponen tendensi sentral, pengukuran variabilitas dan evaluasi ASR.

Pada ASR, akan dilakukan perbandingan nilai yang diperoleh pada komponen tendensi sentral untuk dibandingkan dengan standar yang ditetapkan oleh IAAO yang merupakan organisasi internasional yang berhubungan dengan pajak tanah. Untuk kemudian ditentukan bagaimana NJOP yang berlaku di Desa Pamijahan, Kecamatan Plumbon, Kabupaten Cirebon sudah sesuai dengan standar yang ditetapkan IAAO.

\subsection{Alat dan Bahan}

Dalam penelitian ini, alat yang digunakan yaitu Microsoft Word 2013, Microsoft Excel 2013, Software ArcGis, Software AutoCad dan bahan yang digunakan adalah Data ZNT, Data NJOP, Peta Bidang, Peta Blok, Peta Pendaftaran Desa Pamijahan, Kabupaten Cirebon

\section{HASIL DAN PEMBAHASAN}

Data yang dianalisis adalah nilai NJOP dan ZNT diperoleh melalui overlay union antara peta bidang, peta pendaftaran peta blok, peta ZNT dan peta NJOP dengan sampel sejumlah 19. 
N. A. Baisaku et al.

\subsection{Assesment Ratio (AR)}

Tujuan dari Assesment Ratio adalah membandingkan NJOP dengan ZNT dengan NJOP sebagai assessment value dan nilai tanah pada ZNT diasumsikan sebagai market value.

Tabel 1 Data nilai AR Desa Pamijahan

\begin{tabular}{|c|c|c|}
\hline No. & $\mathbf{A R}=\frac{\boldsymbol{A}_{\boldsymbol{i}}}{\boldsymbol{s}_{\boldsymbol{i}}}$ & $\mathbf{A R \%}$ \\
\hline 1 & 0,266666667 & 26,66667 \\
\hline 2 & 0,046511628 & 4,651163 \\
\hline 3 & 0,113564669 & 11,35647 \\
\hline 4 & 0,015202703 & 1,52027 \\
\hline 5 & 0,082687339 & 8,268734 \\
\hline 6 & 0,027027027 & 2,702703 \\
\hline 7 & 0,157248157 & 15,72482 \\
\hline 8 & 0,201892744 & 20,18927 \\
\hline 9 & 0,105943152 & 10,59432 \\
\hline 10 & 0,034628378 & 3,462838 \\
\hline 11 & 0,201474201 & 20,14742 \\
\hline 12 & 0,040601504 & 4,06015 \\
\hline 13 & 0,2 & 20 \\
\hline 14 & 0,12035473 & 12,03547 \\
\hline 15 & 0,02027027 & 2,027027 \\
\hline 16 & 0,072180451 & 7,218045 \\
\hline 17 & 0,148148148 & 14,81481 \\
\hline 18 & 0,043496622 & 4,349662 \\
\hline 19 & 0,103703704 & 10,37037 \\
\hline TOTAL & 2,001602094 & 200,1602 \\
\hline & & \\
\hline
\end{tabular}

Tabel 1 menunjukkan bahwa nilai AR terendah terdapat pada sampel tanah nomor 4 sebesar 0,015202703 dan perbandingan harga tanah berdasarkan NJOP dengan ZNT sebesar 1,152027\% dan nilai AR tertinggi terdapat pada sampel tanah nomor 1 sebesar 0,26666667 yang keduanya masih jauh dengan aturan IAAO yang menetapkan semua jenis objek pajak dalam suatu daerah seharusnya berada dalam kisaran antara 90\% hingga $110 \%$. Hal ini dapat menimbulkan kerugian bagi 
pemerintah daerah atas hilangnya potensi penerimaan pajak tanah yang secara tidak langsung mempengaruhi pendapatan asli daerah.

\subsection{Pengukuran Tendensi Sentral}

Pengukuran tendensi sentral bertujuan untuk mengetahui besarnya mean, median, weighted mean, perbandingan antara mean dan median serta perbandingan antara mean dengan weighted mean sebagai gambaran awal mengenai karateristik $A R$ di Desa Pamijahan, Kecamatan Plumbon, Kabupaten Cirebon berdasarkan pengujian statistik sederhana dari sampel. Pengukuran tendensi sentral diolah menggunakan Microsoft Excel. Berikut adalah hasil pengukuran tendensi sentralnya:

1. Mean, yang merupakan rata-rata hitung dari jumlah total Assessment Ratio dengan jumlah objek pajak yang diteliti (sampel), yaitu:

$$
\begin{aligned}
\overline{A R} & =\frac{\sum_{i=1}^{n} A R_{i}}{n} \\
& =\frac{2,001602094}{19} \\
& =0,105347479 .
\end{aligned}
$$

Hasil perhitungan mean menunjukkan bahwa di Desa Pamijahan, Kecamatan Plumbon, Kabupaten Cirebon rata-rata dari penilaian NJOP berada di bawah nilai tanah pada ZNT yaitu sebesar $10,53 \%$.

2. Median, yang diperoleh dengan mengurutkan nilai $A R$ tiap sampel dari yang terkecil hingga terbesar. Nilai yang berada di tengah merupakan median sampel yang diteliti. Karena sampel berjumlah ganjil, maka median diperoleh dengan perhitungan berkut:

$$
\begin{aligned}
A R_{m e} & =A R_{(n+1) / 2} \\
& =A R_{(19+1) / 2} \\
& =A R_{10} \\
& =0,103703704 .
\end{aligned}
$$


Hasil median menunjukkan bahwa di Desa Pamijahan, Kecamatan Plumbon, Kabupaten Cirebon nilai tengah dari penetapan NJOP terhadap nilai tanah pada ZNT adalah 0,103703704

2. Weighted Mean, yang merupakan rata-rata tertimbang dari sampel yang diteliti dapat diperoleh dengan perhitungan sebagai berikut:

$$
\begin{aligned}
A R_{w-\text { mean }} & =\frac{\sum_{i=1}^{19} A_{i}}{\sum_{i=1}^{19} S_{i}} \\
& =\frac{1.218 .000}{19.848 .000} \\
& =0,061366385 .
\end{aligned}
$$

Hasil pehitungan weighted mean menunjukkan bahwa di Desa Pamijahan, Kecamatan Plumbon, Kabupaten Cirebon bobot dari nilai rata-rata NJOP terhadap nilai tanah pada ZNT adalah 6,136\%.

Jika mengacu pada standar yang telah ditetapkan oleh IAAO, hasil pengukuran tendensi sentral baik berupa mean, median, maupun weighted mean masih jauh lebih kecil dari 0,90 (90\%) sebagai kisaran standar yang ditetapkan oleh IAAO. Oleh karena itu, dapat dikatakan bahwa penetapan NJOP di Desa Pamijahan, Kecamatan Plumbon, Kabupaten Cirebon belum mencapai keseragaman/keadilan.

\subsection{Perbandingan Antar komponen Tendensi Sentral}

Perbandingan antar komponen tendensi sentral dapat menunjukkan nilai tanah di Desa Pamijahan terjadi under assessment, over assessment, atau tidak keduanya. serta dapat diketahui pula nilai tanah di Desa Pamijahan terjadi progresivitas, regresivitas, atau proporsional. Rincian perhitungannya adalah sebagai berikut:

\section{Mean dibagi dengan Median}

Untuk mengetahui apakah terjadi under assessment, over assessment atau tidak keduanya di Desa Pamijahan, Kecamatan Plumbon, Kabupaten Cirebon maka dilakukan perbandingan antara mean dengan median dengan peritungan sebagai berikut: 


$$
\begin{aligned}
\frac{\overline{A R}}{A R_{m e}} & =\frac{0,105347479}{0,103703704} \\
& =1,015850684 .
\end{aligned}
$$

Dari hasil perhitungan terlihat bahwa nilai mean dibagi dengan median adalah lebih besar dari 0,90 dan kurang dari 1,10 yang berarti sampel yang diambil dalam penelitian di Desa Pamijahan, Kecamatan Plumbon, Kabupaten Cirebon cenderung berimbang antara yang berada dibawah nilai rata-rata AR dan yang berada di atas nilai rata-rata AR.

\section{Mean dibagi dengan Weighted Mean}

Untuk mengetahui terjadi progresivitas, regresivitas, atau tidak terjadi progresivitas maupun regresivitas (proporsional) di Desa Pamijahan, Kecamatan Plumbon, Kabupaten Cirebon, maka dilakukan perbandingan antara mean dengan weighted mean pada perhitungan berikut:

$$
\begin{aligned}
\frac{\overline{A R}}{A R_{\text {w-mean }}} & =\frac{0,105347479}{0,061366385} \\
& =1,716696844 .
\end{aligned}
$$

Dari hasil perhitungan terlihat bahwa nilai mean dibagi dengan weighted mean adalah lebih besar dari 1,10 yang berarti data yang dianalisis menunjukkan terjadinya regresivitas atau kecenderungan turun di Desa Pamijahan, Kecamatan Plumbon, Kabupaten Cirebon yang berarti semakin tinggi nilai properti, maka rasio antara hasil penetapan dibandingkan dengan nilai pasarnya semakin menurun.

\subsection{Pengukuran Variabilitas}

Pengukuran variabilitas digunakan untuk mengetahui tingkat keseragaman penetapan NJOP di Desa Pamijahan, Kecamatan Plumbon, Kabupaten Cirebon Dalam analisis ASR, pengukuran variabilitas meliputi perhitungan COD dan COV. Rincian perhitungannya adalah sebagai berikut:

1. Koefisien Dispersi (Coefficient of Dispersion)

Koefisien Dispersi yang merupakan ukuran keseragaman dengan nilai median dapat diperoleh dengan perhitungan sebagai berikut: 


$$
\begin{aligned}
C O D & =\frac{100 \%}{A R_{m e}}\left(\frac{\sum_{i=1}^{n}\left|A R-A R_{m e}\right|}{n-1}\right) \\
& =\frac{100 \%}{0,103703704}\left(\frac{1,158735917}{19-1}\right) \\
& =0,667584481 .
\end{aligned}
$$

Hasil perhitungan $C O D$ yang didapat sebesar $0,667584481 \%$ berada di luar rentang yang ditetapkan oleh IAAO yaitu minimal 5\% dan maksimal $20 \%$. Hal ini berarti dalam penetapan NJOP tingkat keseragamannya tidak baik yang mengakibatkan ketidak adilan dalam penetapan NJOP di Desa Pamijahan, Kecamatan Plumbon, Kabupaten Cirebon.

2. Koefisien Variasi (Coefficient of Variation)

Koefisien Variasi yang merupakan ukuran keseragaman dengan nilai mean dapat diperoleh dengan perhitungan sebagai berikut:

$$
\begin{aligned}
\operatorname{COV} & =\frac{100 \%}{\overline{A R}} \sqrt{\frac{\sum_{i=1}^{n}(A R-\overline{A R})^{2}}{n-1}} \\
& =\frac{100 \%}{0,105347479} \sqrt{\frac{0,097957947}{19-1}} \\
& =70,02601923 \% .
\end{aligned}
$$

Hasil perhitungan COV sebesar 70,02601923\% lebih tinggi dari standar yang ditetapkan IAAO yaitu maksimal 20\%, sehingga menunjukkan kecenderungan variabilitas yang tinggi. Hasil ini bermakna bahwa analisis ASR di Desa Pamijahan, Kecamatan Plumbon, Kabupaten Cirebon memiliki variasi rasio yang tinggi atau tidak memiliki keseragaman tingkat rasio yang baik.

\subsection{Evaluasi ASR}

Evaluasi hasil analisis ASR yang meliputi uji normalitas distribusi dan uji aras nilai ini memberikan kemaknaan secara statistik yang lebih jauh pada analisis ASR yang dilakukan di Desa Pamijahan, Kecamatan Plumbon, Kabupaten Cirebon. Rincian perhitungannya adalah sebagai berikut: 
1. Uji Normalitas Distribusi

Uji normalitas distribusi digunakan untuk menguji apakah nilai $A R$ di Desa Pamijahan, Kecamatan Plumbon, Kabupaten Cirebon memenuhi asumsi distribusi normal. Jika kenormalan distribusi $A R$ dipenuhi, maka $C O V$ yang dihasilkan memberikan gambaran yang valid mengenai variabilitas nilai $A R$. Berikut ini merupakan plot kenormalan nilai $A R$ yang diperoleh dengan menggunakan uji Kolmogorov-Smirnov dengan menggunakan Minitab 17.

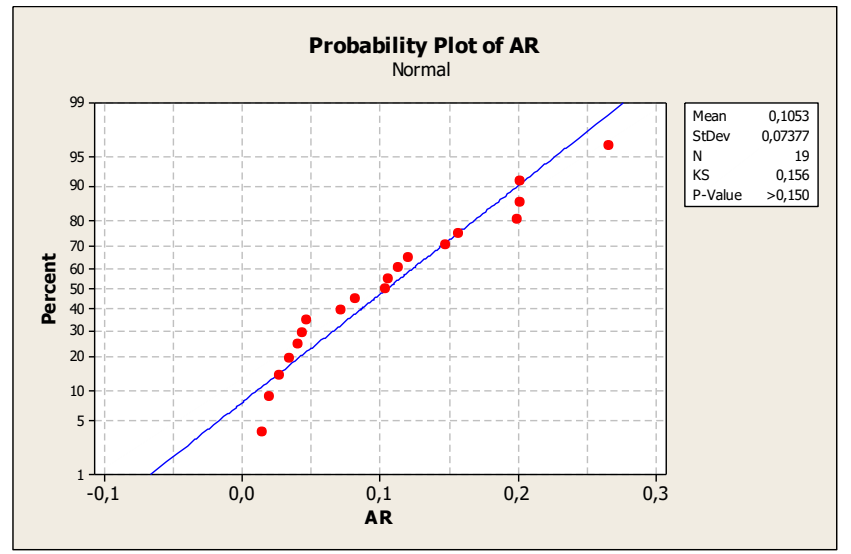

Gambar 1 Plot Kenormalan Nilai AR Uji Kolmogorov-Smirnov

Berdasarkan Gambar 1, dapat dilihat bahwa plot kenormalan nilai $A R$ menyebarsekitar garis linier. Akibatnya, dapat disimpulkan bahwa nilai $A R$ Desa Pamijahan, Kecamatan Plumbon, Kabupaten Cirebon memenuhi asumsi distribusi normal dengan output nilai uji Kolmogorov-Smirnov adalah 0,156 dan $p$-value adalah lebih dari 0,150 yang dapat dilihat pada window-graph Minitab. Kemudian, uji kenormalan nilai $A R$ dilakukan dengan menggunakan uji Kolmogorov-Smirnov sebagai berikut:

a) Hipotesis

$H_{0}$ : Nilai $A R$ berdistribusi normal.

$H_{1}$ : Nilai $A R$ tidak berdistribusi normal.

b) Taraf signifikansi

$\alpha=5 \%=0,05$

c) Daerah penolakan

$H_{0}$ ditolak jika $p$-value $<\alpha$ 
$H_{0}$ tidak dapat ditolak jika $p$-value $>\alpha$

d) Keputusan

Karena $p$-value $>0,150>\alpha=0,05$, maka $H_{0}$ tidak dapat ditolak.

e) Kesimpulan

Karena $H_{0}$ tidak dapat ditolak, maka dapat disimpulkan bahwa pada taraf signifikansi 5\%, nilai $A R$ berdistribusi normal. Jadi, asumsi kenormalan nilai $A R$ terpenuhi dan $C O V$ memberikan gambaran yang cukup valid mengenai variabilitas nilai $A R$.

2. Uji Aras Nilai (testing the level of assesment)

Uji aras nilai dilakukan untuk melihat apakah nilai $A R$ di Desa Pamijahan, Kecamatan Plumbon, Kabupaten Cirebon sesuai dengan nilai tanah sebenarnya yang ada pada ZNT. Pengujian aras nilai ini dilakukan dengan menggunakan One Sample t-Test dengan bantuan aplikasi Minitab dan output hasil uji One Sample t-Test-nya adalah seperti yang terlihat pada Gambar 2 berikut ini.

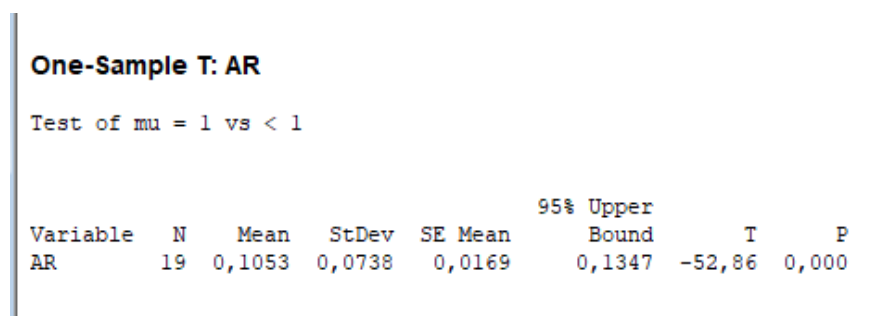

Gambar 2 Output One Sample t-Test Nilai AR

Nilai AR diuji menggunakan One Sample t-Test sebagai berikut:

a) Hipotesis

$H_{0}$ : Rerata nilai $A R$ sama dengan 1,00 .

$H_{1}$ : Rerata nilai $A R$ kurang dari 1,00 .

b) Taraf signifikansi

$\alpha=5 \%=0,05$

c) Daerah penolakan

$H_{0}$ ditolak jika $p$-value $<\alpha$

$H_{0}$ tidak dapat ditolak jika $p$-value $>\alpha$ 
d) Keputusan

Karena $p$-value $=0,000<0,05$, maka $H_{0}$ ditolak.

e) Kesimpulan

Karena $H_{0}$ ditolak, maka dapat disimpulkan bahwa, pada taraf signifikansi $5 \%$, rerata nilai $A R$ kurang dari 1,00. Jadi, dapat diartikan bahwa rerata nilai $A R$ tidak dinilai sesuai seratus persen terhadap nilai tanah yang sesungguhnya, sehingga dapat menimbulkan kerugian bagi pemerintah daerah atas hilangnya potensi penerimaan pajak.

\section{KESIMPULAN DAN SARAN}

\subsection{Kesimpulan}

Berdasarkan hasil dari pembahasan diperoleh sebagai berikut:

1. Nilai Jual Objek Pajak yang ditetapkan di Desa Pamijahan, Kecamatan Plumbon, Kabupaten Cirebon berada di luar rentang standar yang ditetapkan IAAO yaitu sebesar 0,90 sampai dengan 1,10 (90\%-110\%). Hal ini terlihat dari hasil pengukuran tendensi sentral, yaitu mean sebesar 10,53\%, median sebesar 0,1037 , dan weighted mean sebesar 6,136\%.

2. Perhitungan mean dibagi dengan weighted mean menghasilkan nilai 1,716696844 menunjukkan terjadinya regresivitas atau kecenderungan turun di Desa Pamijahan, Kecamatan Plumbn, Kabupaten Cirebon.

3. Assessment Ratio di Desa Pamijahan, Kecamatan Plumbon, Kabupaten Cirebon tidak menunjukkan keseragaman yang baik ditunjukkan dengan nilai COD sebesar 0,66\% dan nilai COV sebesar 70,02\% yang berada di luar standar yang ditetapkan oleh IAAO yaitu nilai COD dan COV minimal 5\% dan maksimal $20 \%$.

\subsection{Saran}

Penelitian selanjutnya disarankan untuk melakukan overlay langsung terhadap peta NJOP dan peta ZNT serta menambahkan lebih banyak titik sampel tanah yang terdapat pada wilayah penelitian, agar lebih merepresentasikan wilayah penelitian dan hasil perhitungan yang didapat lebih akurat 


\section{DAFTAR PUSTAKA}

Dewi, A.R., Assesment Sales Ratio, Suatu Alat Pengukur Kinerja Penetapan NPOP, Bhumi: Jurnal Agraria dan Pertanahan, 2(1) (2016), 102-114.

Hartoyo, Assessment Sales Ratio Suatu Alat Ukur Pengukur Kinerja Penilaian dalam Pelaksanaan PBB., Modul Penilaian II, Jakarta, 1998.

[IAAO] International Association Assesing Officers, Standard on Ratio Study. Kansas: International Association of Assessing Officers, Kansas, 2013.

[Kemenkeu RI] Kementerian Keuangan Republik Indonesia, Penilaian Pajak Bumi dan Bangunan, Direktorat Jenderal Perimbangan Keuangan, 2018.

Novie, A.S., Analisis Tingkat Akurasi Penetapan NJOP terhadap Nilai Pasar dengan Metode ASR (Studi Kasus di Kecmatan Kelapa Gading Kotamadya Jakarta Utara), Skripsi, Institut Bisnis dan Informatika Indonesia, Jakarta, 2010.

Purnomo, P. dan Sabijono, H., Analisis Penetapan NJOP Bumi Pada PT .Ciputra Internasional Manado Tahun 2015, Jurnal EMBA, 4(1) (2016), 964-972.

Supratno, A., Pengaruh Perubahan Zona Nilai Tanah dan Nilai Jual Objek Pajak Bangunan Terhadap Penerimaan Pajak Bumi dan Bangunan Perdesaan dan Perkotaan di Kabupaten Sambas, Skripsi, Universitas Tanjungpura, 2018.

Wita, S., Analisis Assesment Sales Ratio Antara Nilai Jual Objek Pajak dengan Harga Jual Tanah dan Bangunan, Skripsi, Universitas Brawijaya, 2007. 